\title{
Regulation of The Utilization of Oil and Gas in the Sea Border Region Based on International Law
}

\author{
Richard Marsilio Waas*, Farida Patittingi, ${ }^{* *}$ Muhammad Ashri, ${ }^{* *}$ Marcel Hendrapati ${ }^{* *}$ \\ *Doctoral Student, Postgraduate Program, Faculty of Law, Hasanuddin University, Indonesia \\ ${ }^{* *}$ Professor on Legal Science, Faculty of Law, Hasanuddin University, Indonesia
}

\begin{abstract}
The border region is a very strategic area for security, social and economic stability, both the border communities and all citizens in a country. The border region in Indonesia too. Indonesia's vast border region requires effective and accountable border management policies from social, economic and security aspects. The use of oil and gas in international law studies is contained in the legal instruments of the United Nations General Assembly Resolution 1803 (XVII) on December 14, 1962, Resolution 2158 (XXI) on November 25, 1966, and Resolution 3016 (XXVNI) on 18 December 1972, United Nations General Assembly Resolution (FEB) 3201 (SV1) May 1, 1974 concerning the Declaration on the Establishment of a New International Economic Order and Resolution 3281 (XXIX) December 12, 1974 concerning the Program of Economic Rights and Obligations of the State, and the 1972 Declaration on the Human Environment.
\end{abstract}

Keywords: regulation, utilization, oil and gas, sea borders, international law

DOI: $10.7176 /$ RHSS/9-18-13

Publication date:September $30^{\text {th }} 2019$

\section{Introduction}

The blessing for a nation is to have abundant natural resources. One such source of wealth is oil and gas. Ideally owned natural wealth will have a positive impact on economic growth and good economic growth will also have an impact on improving living standards and welfare. Indonesia as one of the countries that have oil and gas natural resources in the world is faced with various complex problems, one of which is the location or location of oil and gas resources located in the sea border area. The border area is a phenomenal aspect due to the multidimensional border problem. Issues that are quite prominent are various violations of sovereignty over the territory of the country, unilateral claims to the ownership of natural resources, islands and territorial territories of one country by another country. Therefore, the determination and affirmation of a country's boundaries is felt to be very important and urgent, it is based on the fact of the rapid growth and development of development that requires new space for these activities. The need for this space will ultimately affect the loss or change of a country's territorial boundaries, with changes in the country's territorial borders it will also have an impact on the utilization and management of natural resources.

Determination of national borders in the form of regulations becomes important when the interaction of world countries starts to deny borderless territories as a result of changing global situations in various regions. The problem of national borders is not only related to threats and interference from outside, but also relates to the sovereignty of the country's territory and the rights of citizens to explore natural resources and resources in the national territory.

International law has made quite an important contribution, especially in the implementation of negotiations and the signing of agreements or agreements between countries. Regulations regarding the determination of a country's maritime boundaries and various activities at sea have actually been contained in a comprehensive international agreement known as UNCLOS 1982 (United Nations Convention on the Law of the Sea 1982). In UNCLOS 1982 there are eight regulatory zones (regimes) applicable to the sea, namely (1) internal waters, (2) archipelagic waters, (3) territorial waters, (4) contiguous zone, (5) Exclusive Economic Zone, (6) continental shelf, (7) high seas, and (8) international seabed area.

Indonesia itself has ratified UNCLOS 1982 through Law of the Republic of Indonesia No. 17 Year 1985 and enacted Law of the Republic of Indonesia No. 6 Year 1966 concerning Indonesian Waters replacing Law of the Republic of Indonesia No. 4/Perp.1960 which is adapted to the spirit or provisions of UNCLOS 1982. Furthermore, for the purposes of determining the territorial boundaries of Indonesian waters, it has been outlined in Government Regulation of the Republic of Indonesia No. 38 Year 2002 concerning the Geographic Coordinate List of Indonesian Archipelagic Lines. However, in reality up to now, there are still incomplete boundaries between Indonesia and neighboring countries. 
Geographically, the Indonesian archipelago is flanked by two continents, Asia and Australia and two oceans, the Pacific and Indian oceans. Indonesia is the largest archipelago country in the world with a number of large and small islands reaching 17,504, and the area of the waters reaching 5.8 million $\mathrm{km} 2$, and the length of the coastline of approximately $95,181 \mathrm{~km} .{ }^{1}$ and has been added to the length of the coastline $(99,093 \mathrm{~km}){ }^{2}$ Indonesia also has archipelago characteristics with sovereignty over land, sea and air areas and has sovereign rights outside its sovereign territory in the form of natural resources to be managed and utilized for the prosperity of all people. With its strategic geographical position and broad geographical location will make Indonesia a nation that can influence various events in the world, and will certainly affect the management and utilization of natural resources in the sea area.

The existence of Indonesia as the Unitary State of the Republic of Indonesia (NKRI) will be influenced by the conditions and its geographical location so that the management of natural resources, border areas is needed. Indonesia's sea area is bordered by ten countries, namely India, Thailand, Vietnam, Malaysia, Singapore, the Philippines, the Republic of Palau, Papua New Guinea (PNG), Australia, and the Democratic Republic of Timor Leste. While Indonesia's land area is directly bordered by three countries, namely Malaysia, Papua New Guinea, and Timor Leste with the total length of the land border line being $\left(2914.1 \mathrm{~km}\right.$.). ${ }^{3}$ History shows that its strategic location makes Indonesia contested by large countries to be made a colony long ago. Several countries were recorded as having tried to dominate Indonesia, such as Portugal, the Netherlands, Japan, the United States, and the Soviet Union during the Cold War era. Until now, Indonesia is still a contested area of influence by large countries, including China and Korea, thus border disputes, such as with Australia, the Philippines, Malaysia, Papua New Guinea, and Timor Leste also have great potential to occur in Indonesia.

Borders, especially state borders are one of the important aspects in world geopolitics. State borders are the main manifestation of the territorial sovereignty of a country. Border of a country has an important role in determining the boundaries of sovereignty, utilization of natural resources, and maintaining the security and integrity of the region. State borders are in many ways determined by historical, political and national and international legal processes. ${ }^{4}$

The border region is a very strategic area for security, social and economic stability, both the border communities and all citizens in a country. The border region in Indonesia too. Indonesia's vast border region requires effective and accountable border management policies from social, economic and security aspects. However, so far, conditions on the ground indicate that border management systems in Indonesia tend to be less effective and accountable. Management of the border region is closely related to the basic conception of the state as an entity that has sovereignty, population, territory, and perception of the threats faced.

Geopolitical views in Indonesia are known as the archipelago insight. This view was developed from a universal theory of national insight that was imbued and shaped by the understanding of the power of the Indonesian people and Indonesian geopolitics. This view has the principle of creating national unity and territorial integrity of the Republic of Indonesia based on the spirit of Unity in Diversity in the framework of equality, justice, togetherness, and national interests. The concept of the archipelago insight is in line with Karl Houshofer's geopolitical view of the concept of lebensraum (living space) or Ratzel's explanation that humans are the same as organisms that need living space and the concept of autarchy, namely the ideals to meet the needs of one's own country without relying on other countries. ${ }^{5}$

State borders are physical borders of a state expressing the sovereignty of the state and sovereign rights in the form of national power in general, legal power better known as national jurisdiction in particular. Through borders, countries and/or residents around the region interact both directly and indirectly. The use of marine natural resources in border areas is an important issue related to the boundaries of an area, island and the sovereignty and existence of a state territory. Borders often trigger conflicts between neighboring countries because borders are not just the frontiers or front lines of a country. Borders are seen as a symbol of the sovereignty and existence of a country.

\footnotetext{
${ }^{1}$ Freddy Numbery, Pengelolaan Pulau-pulau kecil terluar, Buletin Kelautan P3K Kementerian Kelautan dan Perikanan.Vol. IV. No. I. March 2006, p.12-25

2 Priyadi Kardono, Garis Pantai Indonesia, Working Paper, 2016.

${ }^{3}$ Madu, L., et.al. Mengelolan Perbatasan Indonesia di Dunia Tanpa Batas. Yogyakarta, 2010, p.20

4 Moeldoko,. "Kompleksitas Pengelolaan Perbatasan: Tinjauan dari Perspektif Kebijakan Pengelolaan Perbatasan Indonesia" dalam Makalah Seminar "Pengelolaan Sumber Daya Alam dalam Perspektif Ketahanan Nasional”. Universitas Tanjungpura Pontianak, May 8, 2014, not published.

${ }^{5}$ Sunarso, et.al., Pendidikan Kewarganegaraan untuk Perguruan Tinggi. Yogyakarta: UNY Press. 2008, p.27
} 
Border territorial area is a manifestation of the sovereignty of an area, be it the territory of the State, or an area whose scope is narrower. Because basically the existence of a territorial territory can be demonstrated by the way the State arranges and manages its borders. The implementation of the development program in the border region as well as guarantees of the sovereignty and integrity of the territory of the Republic of Indonesia have been set forth in Law of the Republic of Indonesia Number 43 Year 2008 concerning State Territories. The issuance of Law of the Republic of Indonesia No. 43 Year 2008 shows that the actual borders of the State are inseparable from the legal status of the territory of the State itself. The legal status of a State Territory always continues or coexists with a different territory and sovereignty of the State. In maintaining political, economic, social and security stability, there is a need for an agreement regulating borders between countries so as not to cause cross-border disputes, especially in the utilization of natural oil and gas resources.

Management and utilization of oil and gas natural resources as regulated in Law of the Republic of Indonesia Number 22 Year 2001 concerning Oil and Gas, aims to: ${ }^{1}$ First. Implemented and controlled oil and gas as natural resources and strategic development resources. Second. Supporting and developing national capabilities to be more able to compete. Third. Increase in state income and contribute as much as possible to the national economy, develop and strengthen Indonesia's industry and trade. Fourth. Creating jobs, improving the environment, increasing the welfare and prosperity of the people.

But in reality, that Law of the Republic of Indonesia No. 22 Year 2001 concerning Oil and Gas, has created an energy policy that tends to be sectoral and is oriented only to the aspect of income, not to national security in the energy sector. This was reinforced by the cancellation of three times by the Constitutional Court of the Republic of Indonesia. ${ }^{2}$

First. Decision of the Constitutional Court of the Republic of Indonesia No. 002/PPU-I/2003. The decision of the Constitutional Court is to revoke Article 28 paragraph (2) and Paragraph (3) which submits the determination of the price of fuel and gas to the competition mechanism. The Court is of the opinion that there must be government intervention in the policy of determining the price of fuel and gas. Because, both are important branches of production and control the lives of many people. In addition, the Court also revised part of the contents of the other two Articles. First, Article 12 paragraph (3) regulates the authority of the Minister of Energy and Mineral Resources in determining business entities that are entitled to explore and exploit. Second, Article 22 paragraph (1) which requires business entities to submit a quarter of their production results for domestic needs.

Second. Decision of the Constitutional Court of the Republic of Indonesia No. 20/PUU.V/2007. Namely that Article 11 paragraph (2) of the Oil and Gas Law is contrary to Article 20A and Article 33 paragraph (3) of the 1945 Constitution of the Republic of Indonesia. Third. Decision of the Constitutional Court of the Republic of Indonesia No. 36/PUU-X/2012 Concerning judicial review to Law of the Republic of Indonesia No. 22 Year 2001 concerning Oil and Gas. In its decision, the Constitutional Court annulled 18 provisions related to the position, function and duties of the Executive Agency for Upstream Oil and Gas Business Activities (BP Migas). In essence, the Constitutional Court is of the opinion that BP Migas is in conflict with the Constitution. As a result, BP Migas must be dissolved and replaced with the Establishment of a Special Upstream Oil and Gas Business Unit (SKK Migas) through Presidential Regulation of the Republic of Indonesia Number 9 Year 2013.

Judicial review of Law of the Republic of Indonesia No. 22 Year 2001 concerning Oil and Gas, as a sign that regulations on the management and utilization of oil and gas natural resources are still far from a sense of justice. Regulations that do not provide a sense of justice will certainly cause conflicts both internally (nationally) and externally (internationally).

External conflicts in sea border areas often occur, the following is one of the border conflicts that have occurred in Indonesia. Border Conflict in the South China Sea, where Indonesia's territorial borders consist of territorial sea boundaries, EEZ boundaries, continental shelf boundaries and additional zone boundaries. In these areas, a common condition is that there are violations of sea boundaries, both by neighboring state officials and their communities who carry out illegal activities. In addition, "there are still a number of boundary lines between Indonesia and neighboring countries". ${ }^{3}$ The fact shows that there are still vulnerable border areas between countries against various problems that are multidimensional. The unclear determination of boundaries between countries is one of the triggers for the emergence of these problems. In this regard, an understanding of

\footnotetext{
${ }^{1}$ Salim HS, Hukum Pertambangan di Indonesia, Jakarta, RajaGrafindo Persada, 2004, p.284

${ }^{2}$ www.hukumonline, dated 24 February 2015

${ }^{3}$ Hikam, M, A., Menyongsong 2014-2019: Memperkuat Indonesia dalam Dunia yang Berubah. Jakarta: 2014, p.334-335
} 
the conception of the State, State territory and territorial boundaries is the first step for the creation of a comprehensive understanding of the importance of the State border region, especially for the creation of a situation conducive to the sovereignty and territorial integrity of a State.

Maluku is one of the international shipping lanes and at the same time a region bordering directly with other countries, namely Australia and Timor Leste, while Natuna Regency, Riau Islands Province is also an international shipping line and at the same time borders with another, namely the northern part of Natuna bordering Vietnam and Cambodia, in the south bordering South Sumatra and Jambi, in the west bordering Singapore, Malaysia and Riau, and in the east with East Malaysia and West Kalimantan. Natuna Regency is famous for producing oil and gas. Natuna oil reserves are estimated at 1,400,386,470 barrels, while natural gas reaches 112,356,680,000 barrels. Besides that, Maluku itself has marine natural resources especially oil and gas which is very large, one of which is the natural wealth of oil and gas located on the island of Masela, Southwest Maluku Regency, Maluku Province and has been managed by foreign companies in cooperation with the Indonesian government. Utilization of natural resources of the sea Oil and Gas is bordered by Timor Leste, and also Australia.

The issue of sovereignty which includes aspects of the utilization of natural resources is a crucial aspect that will be faced by every country including Indonesia in an increasingly competitive global arena. This is because the natural resources, especially oil and gas owned by Indonesia are very abundant. Up to now oil and gas management still plays a very important role to support the sustainability of Indonesia's development, both as one of the mainstays of foreign exchange earners as well as suppliers of domestic energy needs that affect the national economy. Based on this influence, the oil and gas wealth owned by Indonesia can be stated as the most important aspect of the nation's potential. Based on the explanation, the problem that will be discussed in this paper is how to use oil and gas in the perspective of international law? and how to regulate the utilization of oil and gas in Indonesia?

\section{Research Method}

This type of research is normative legal research ${ }^{1}$ with the statutory approach and conceptual approach. ${ }^{2}$ The data used are secondary data collected through documentation studies. The collected data is then analyzed qualitatively.

\section{Results and Discussion}

\section{III.1. Utilization of Oil and Gas in International Law Perspective}

Oil and gas are a type of natural resource with strategic value which is controlled by the state and is a vital commodity that controls the lives of many people and has an important role in the economy of each nation and country. From the perspective of international law, an in-depth study of natural resources initially was not an object of study to be analyzed in the field of international law. It's just because the study of the concept of permanent sovereignty of natural resources that continues to develop makes the study of natural resource law become one of the many branches of discussion in international law. This is in line with Nico Schrijver's explanation that: ${ }^{3}$

"Permanent so vereignty over natural resources is one of the more controversial new prinCIp/es of international law that have evolved since world war two. During this pen'od the decolonization process has taken place and newly independent states have sought to develop new principles and rules of intemationai law in order to asse/t and strengthen their position in international relations and to promote their social and economic de velopment".

Another view from Ricardo Pereira states that: ${ }^{4}$

\footnotetext{
${ }^{1}$ Soerjono Soekanto and Sri Mamudji, Penelitian Hukum Normatif; Suatu Tinjauan Singkat, Rajawali Press, Jakarta. 2004, p. 13-14

${ }_{2}^{2}$ Peter Mahmud Marzuki, Penelitian Hukum, Prenadamedia Group Jakarta, Jakarta: Kencana Prenada Media Group, 2005, p.35

${ }^{3}$ Nico Schn'jver, 1997, Sovereignty Over Natural Resources: Balancing Rights and Duties, Cambridge: Cambridge University Press, p.1

4 Imam Mulyana. 2016, "The Development of intemationai Law in the Fietd of Renewable Energy”, Volume 2 Issue 1. April 2016, Hasanuddin Law Review, Faculty of Law Hasanuddin University, p.41
} 
"The history of international law noted that before 1945, the natural resources is not an object of study that systematically studied in international law, but the development of the concept of sovereignty permanently to the natural resources, and the development of the law of the sea have made the birth of the law of natural resources as a new branch of international law."

Furthermore according to Ricardo Pereira that:

"After 1945, the future of international law in the field of natural resources further the subject of discussion in various forums and influencing the policy makes and lawmakers, mainly deals with the issue of environmental damage threat caused by the exploration and exploitation of natural resources". ${ }^{1}$

In binding agreements with other countries, there must have previously been a joint political will from each party who wanted to bind the agreement. The political will is manifested in the form of a conceptual process from each party that will be confronted in the negotiations. Bargaining in the concept argumentation procedure is the initial formula of the will of each party. Of course, in the bargaining power that is demanded the art of political argumentation by proposing the interests of each party. ${ }^{2}$ When discussing the legal basis that forms the basis of jurisdiction in the framework of international law in relation to the management of natural resources, especially oil and gas, will not be separated from various international legal instruments that govern the principle of state sovereignty over the right to control natural resources. The principle of sovereignty or the right to control the state over natural resources is not something new and has even been fully recognized by international law as can be found in various official documents. The documents are framed in various international legal instruments in relation to the management of natural resources, among others, as follows:

1. United Nations General Assembly Resolution (FEB) 1803 (XVII) December 14, 1962, Resolution 2158

(XXI) November 25, 1966, and Resolution 3016 (XXVNI) December 18, 1972. This Resolution broadens

the scope of the tenure principle permanent (sovereignty) of natural resources on the seabed and the land beneath which is still in the national jurisdiction of a country. ${ }^{3}$

Alma Manuputty, et.al., mentioned that the idea of the importance of placing the decision (resolution) of the UN General Assembly as a source of international law. ${ }^{4}$ Resolution 1803 (XVII) also emphasizes the interests of national development and the welfare of the people of the country concerned and emphasizes that economic agreements including investment are for independent national development and are based on the recognition of each country of the right to control wealth and natural resources. In resolution 1803 of 1962 the permanent control of natural resources, it was stated that in every country the full control of natural resources and all economic activities. Exploration, development and utilization of these resources along with the foreign capital needed for this purpose must be in accordance with the rules and conditions in which the community and the nation concerned consider the need for authorization, restrictions or restrictions on these activities. ${ }^{5}$ Resolution 1803 has then become the legal basis for developing countries to request improvements to the terms and conditions of concession agreements, while several other non-binding resolutions are the political basis that can be used to encourage change. The resolutions recognize the right of the state to nationalize foreign ownership, which results in increased uncertainty and risk of loss for foreign companies, thereby increasing the bargaining position of the host countries. ${ }^{6}$ Every flag State which receives a report of an infringement of a safety zone by a vessel flying its flag should make inquiries, take action, where appropriate, in accordance with its national legislation and inform, as appropriate, the coastal State concerned of the follow-up action it has taken. ${ }^{7}$

\footnotetext{
${ }^{1}$ Ibid.

2 S.M. Noor, Politik Hukum Ratifikasi Indonesia, Makassar: Pustaka Pena Press, 2016, p.1

3 Huala Adolf, 2002, Aspek Aspek Negara dalam Hukum Intemasional, Jakarta: PT, Grafindo Persada, p.5354.

4 Alma Manuputty, et.al., Hukum Internasional, Depok: Rech-ta in collaboration with Pusat Penerbitan Fakultas Hukum Universitas Hasanuddin, 2008, p.145

5 UN General Assembly Resolution 1803 (XVII). December 14, 1962, Permanent Sovereignty Over Natural Resources. Resolution 1803 was adopted by the United Nations General Assembly with a vote of 87 approves and 2 refused. Among the countries that approve are the United States and several western countries, so resolution 1803 can be said to be binding.

${ }^{6}$ A. Madjedi Hasan, Kontrak Minyak dan Gas Bumi Berazas Keadilan dan Kepastian Hukum, Jakarta: Fikahati Aneska, 2009, p.36.

${ }^{7}$ Marcel Hendrapati, et.al., Pengaturan Hukum Mengenai Instalasi Lepas Pantai dan Zona-Zona Keselamatan, Makassar: Pustaka Pena Press, 2019, p.172.
} 
Resolution 2158 (XXI) is the first attempt in terms of linking the state's right to control natural resources with various demands from developing countries to obtain a larger and profitable portion in the processing, marketing and distribution of natural resources.

2. United Nations General Assembly Resolution (FEB) 3201 (S-V1) May 1, 1974 concerning the Declaration on the Establishment of a New International Economic Order and Resolution 3281 (XXIX) December 12, 1974 concerning the Program for Economic Rights and Obligations of the State (Charter) of Economic Rights and Duties of States), which reaffirms the right of control by the state to monitor its natural resources in an effort to increase economic growth. Resolution 3201 confirms that the new international economic system should be based on, among other things, the full control of the state and to secure these natural resources, each country has the right to control and exploit it, which includes nationalizing or transferring ownership to its own country.

The fact that all countries must pursue their own national interests means that other countries and governments can never be fully expected. All international agreements are temporary and conditional on the basis of the desire of countries to comply. ${ }^{1}$ Article 1 of Chapter II Resolution 3281 states that each country has sovereignty and inalienable rights (rights that cannot be surrendered or transferred without the consent that has the right) to choose the economic system as well as the political, social and cultural system based on the will of its people, without outside intervention, coercion or threat in all forms. Next in Article 2 Chapter II emphasizes that each country has the right and is free to exercise its rights, including owning, using and releasing its wealth, resources and economic activities. International Covenant on Economic, Social and Cultural Rights (ICESR) Article 1 and International Covenant on Civil Political Rights (ICCPR) Article 1 Date 16 December 1966. This international agreement affirms the right of a country to make free use of its natural resources. The ICESR and ICCPR which are part of the Universal Declaration of Human Rights of 1948 are international treaties produced by the United Nations General Assembly and entered into force January 3, 1976. This agreement contains an agreement to work together in giving economic, social and cultural rights to each individual and/or nation.

3. Declaration on the Human Environment 1972 in Stockholm.

The declaration is an agreement and contains general provisions whereby the parties to the declaration promise to carry out certain policies in the future; declaration contains more political commitments whose contents are concise and concise and overrides procedural provisions that are formal in nature such as a full powers ratification and others. ${ }^{2}$

Article 11 and 12 affirm that the state has the sovereign right to utilize its natural resources in accordance with their respective environmental preservation policies. In utilizing these natural resources, the state is responsible for activities that harm the environment, both in its own territory and in the territory of other countries (Articles 12 and 11). The Stockholm Declaration also emphasizes the need for good planning and management to save natural resources for the benefit of present and future generations.

\section{III.2. Regulations on the Use of Oil and Gas in Indonesia}

Legally the law governing oil and gas, namely Law of the Republic of Indonesia Number 22 Year 2001 concerning Oil and Gas aims to:

1) the implementation and control of oil and gas as natural resources and development resources that are strategic and vital.

2) support and develop national capabilities to be more able to compete,

\footnotetext{
1 S.M. Noor, et.al., Hukum Diplomatik dan Hubungan Internasional, Makassar: Pustaka Pena Press, 2016, p.190; Mutual Benefit Principle in relations between countries requires that the subjects of international law (especially the state) in carrying out international relations be based on good faith so as to benefit all parties. Mutual benefit principle requires equal rights, namely that all parties strive to be mutually beneficial to each other, initially this principle is used to accommodate the nature and purpose of the business. But along with the times and to meet needs that are already cross-country, then this principle can be used as a reference in international relations, especially bilateral relations between the two countries, although this principle is also in accordance with the context of multilateral relations between many countries. See Kadarudin, Thamrin, H., Liao, I.-M., \& Satalak, P. (2019). Mutual Benefit Principle As Bilateral Basis of Indonesia With Thailand And Taiwan. International Journal of Global Community,2(1 - March), 33-52. Retrieved from https://journal.riksawan.com/index.php/IJGC-RI/article/view/10

${ }^{2}$ Muhammad Ashri, Hukum Perjanjian Internasional, Dari Pembentukan Hingga Akhir Berlakunya, Makassar, Arus Timur, 2012, p.18
} 
3) increasing state revenues and contributing as much as possible to the national economy, developing and strengthening Indonesia's industry and trade, and

4) creating jobs, improving the environment, increasing the welfare and prosperity of the people. ${ }^{1}$

Other laws and regulations.

1) Government Regulation of the Republic of Indonesia No. 35 Year 1994 concerning Terms and Guidelines for Cooperation in Oil and Gas Production Sharing Contracts?

2) Presidential Decree of the Republic of Indonesia No. 42 Year 1989 concerning Pertamina's Cooperation with the Oil and Gas Purification and Processing Business Entity;

3) Government Regulation of the Republic of Indonesia No. 41 Year 1982 concerning Obligations and Procedures for Depositing Government Revenues from the Results of Pertamina Own Operations and Production Sharing Contracts;

4) Decree of the President of the Republic of Indonesia Number 169 Year 2000 concerning Principles 'Pertamina's Organization;

5) Government Regulation of the Republic of Indonesia No. 42 Year 2002 concerning the Agency for Implementing Upstream Oil and Gas Business Activities;

6) Government Regulation of the Republic of Indonesia Number 55 Year 2009 Second Amendment to Government Regulation Number 35 Year 2004 Concerning Upstream Oil and Gas Business Activities;

7) Presidential Regulation of the Republic of Indonesia No. 9 Year 2013 concerning the Management of Upstream Oil and Gas Business Activities;

8) Presidential Instruction No. 2 Year 2012 concerning Increasing National Petroleum Production;

9) Decree of the Minister of Energy and Mineral Resources of the Republic of Indonesia Number $1088 \mathrm{~K} / 20 / \mathrm{Mem} / 2003$ concerning Guidelines for the Implementation of Supervision, Supervision, Regulation and Control of Upstream Oil and Gas Business Activities and Downstream Oil and Gas Business Activities;

10) Regulation of the Minister of Energy and Mineral Resources of the Republic of Indonesia Number 09 Year 2013 concerning Organization and Work Procedures of Special Work Units for Implementing Upstream Oil and Gas Business Activities; and

11) Regulation of the Minister of Energy and Mineral Resources of the Republic of Indonesia Number 38 Year 2015 concerning the Acceleration of Non-Conventional Oil and Gas Business.

The large number of oil and gas working areas needs to be protected by the state and the community. The way for the state to protect and protect the working area is by making regulations relating to oil and natural gas. One such regulation, namely Law of the Republic of Indonesia No. 22 Year 2001 concerning Oil and Gas and various implementing regulations. Legal provisions that study norms relating to oil and gas are called "Oil and Gas Laws”.

\footnotetext{
1 Article 3 of the Law of the Republic of Indonesia Number 22 Year 2001 concerning Oil and Gas
} 


\section{Conclusion}

Based on the description as mentioned above, it can be concluded that the border territorial region is a manifestation of the sovereignty of an area, be it the territory of the State, or an area that is narrower in scope. Because basically the existence of a territorial territory can be demonstrated by the way the State arranges and manages its borders. The implementation of the development program in the border region as well as guarantees of the sovereignty and integrity of the Unitary Republic of Indonesia have been set forth in Law of the Republic of Indonesia Number 43 Year 2008 concerning State Territories. Whereas the management and utilization of oil and gas natural resources as regulated in Law of the Republic of Indonesia No. 22 Year 2001 concerning Oil and Gas. In international law studies, United Nations General Assembly Resolution 1803 (XVII) of December 14, 1962, Resolution 2158 (XXI) of November 25, 1966, and Resolution 3016 (XXVNI) of December 18, 1972, Resolution of the General Assembly of the United Nations Nation (FEB) 3201 (S-Vl) May 1, 1974 concerning the Declaration on the Establishment of a New International Economic Order and Resolution 3281 (XXIX) December 12, 1974 concerning the Program of Economic Rights and Obligations of the State, and the Declaration on the Human Environment in 1972 is the basis for the use of oil and gas.

\section{References}

A. Madjedi Hasan, Kontrak Minyak dan Gas Bumi Berazas Keadilan dan Kepastian Hukum, Jakarta: Fikahati Aneska, 2009.

Alma Manuputty, et.al., Hukum Internasional, Depok: Rech-ta in collaboration with Pusat Penerbitan Fakultas Hukum Universitas Hasanuddin, 2008.

Freddy Numbery, Pengelolaan Pulau-pulau kecil terluar, Buletin Kelautan P3K Kementerian Kelautan dan Perikanan.Vol. IV. No. I. March 2006.

Hikam, M, A., Menyongsong 2014-2019: Memperkuat Indonesia dalam Dunia yang Berubah. Jakarta: 2014.

Huala Adolf, 2002, Aspek-Aspek Negara dalam Hukum Intemasional, Jakarta: PT, Grafindo Persada.

Imam Mulyana. 2016, "The Development of intemationai Law in the Fietd of Renewable Energy", Volume 2 Issue 1. April 2016, Hasanuddin Law Review, Faculty of Law Hasanuddin University.

Kadarudin, Thamrin, H., Liao, I.-M., \& Satalak, P. (2019). Mutual Benefit Principle As Bilateral Basis of Indonesia With Thailand And Taiwan. International Journal of Global Community, 2(1 - March), 3352. Retrieved from https://journal.riksawan.com/index.php/IJGC-RI/article/view/10

Marcel Hendrapati, et.al., Pengaturan Hukum Mengenai Instalasi Lepas Pantai dan Zona-Zona Keselamatan, Makassar: Pustaka Pena Press, 2019.

Madu, L., et.al. Mengelolan Perbatasan Indonesia di Dunia Tanpa Batas. Yogyakarta, 2010.

Moeldoko. "Kompleksitas Pengelolaan Perbatasan: Tinjauan dari Perspektif Kebijakan Pengelolaan Perbatasan Indonesia" dalam Makalah Seminar "Pengelolaan Sumber Daya Alam dalam Perspektif Ketahanan Nasional”. Universitas Tanjungpura Pontianak, May 8, 2014, not published.

Muhammad Ashri, Hukum Perjanjian Internasional, Dari Pembentukan Hingga Akhir Berlakunya, Makassar, Arus Timur, 2012.

Nico Schn'jver, 1997, Sovereignty Over Natural Resources: Balancing Rights and Duties, Cambridge: Cambridge University Press.

Peter Mahmud Marzuki, Penelitian Hukum, Prenadamedia Group Jakarta, Jakarta: Kencana Prenada Media Group, 2005.

Priyadi Kardono, Garis Pantai Indonesia, Working Paper, 2016.

S.M. Noor, Politik Hukum Ratifikasi Indonesia, Makassar: Pustaka Pena Press, 2016.

S.M. Noor, et.al., Hukum Diplomatik dan Hubungan Internasional, Makassar: Pustaka Pena Press, 2016.

Salim HS, Hukum Pertambangan di Indonesia, Jakarta, RajaGrafindo Persada, 2004.

Soerjono Soekanto and Sri Mamudji, Penelitian Hukum Normatif; Suatu Tinjauan Singkat, Rajawali Press, Jakarta. 2004.

Sunarso, et.al., Pendidikan Kewarganegaraan untuk Perguruan Tinggi. Yogyakarta: UNY Press. 2008.

www.hukumonline, dated 24 February 2015 